\title{
PEMANTAUAN TUMBUH KEMBANG BAYI DAN BALITA KECAMATAN SINGAPARNA TAHUN 2017
}

\author{
OLEH : \\ Hariyani Sulistyoningsih, SKM, MKM, Annisa Rachmidini, SST, M.Keb \\ Fenty Agustini, SST, M.Kes, Hapi Apriasih, SST, M.Keb, \\ Lia Yuliastuti, SST, M.Keb, Erwina Sumartini, SST, M.Keb
}

\section{A. DASAR PEMIKIRAN}

Salah satu permasalahan kesehatan di Indonesia adalah keadaan gizi yang kurang baik bahkan buruk. Tercatat satu dari tiga anak di dunia meninggal settiap tahun akibat buruknya kualitas nutrisi. Sebuah riset juga menunjukkan setidaknya 3,5 juta anak meninggal tiap tahun karena kekurangan gizi serta buruknya kualitas makanan. Badan kesehatan dunia (WHO) memperkirakan bahwa 54 persen kematian anak disebabkan oleh karena keadaan gizi yang buruk. Sementara masalah gizi di Indonesia mengakibatkan lebih dari 80 persen kematian anak (WHO, 2011).

Status gizi buruk pada balita dapat menimbulkan pengaruh yang sangat menghambat pertumbuhan fisik, mental maupun kemampuan berfikir yang pada akhirnya akan menurunkan produktivitas kerja. Balita hidup penderita gizi buruk dapat mengalami penurunan kecerdasan (IQ) hingga 10 persen. Keadaan ini memberi petunjuk bahwa pada hakikatnya gizi yang buruk atau kurang akan berdampak pada menurunnya kualitas sumber daya manusia.

Gizi buruk masih menjadi salah satu masalah di Kabupaten Tasikmalaya, pada tahun 2016 jumlah kasus gizi buruk berjumlah 63 kasus, sementara tahun 2017 turun menjadi 41 kasus. Kasus ini dari tahun ke tahun mengalami penurunan, akan tetapi permasalahan gizi kurang masih menjadi masalah nasional yang perlu penanganan serius. Berdasarkan data yang didapat dari profil Puskesmas Singaparna tahun 2016 didapatkan bahwa kasus gizi buruk di Kecamatan Singaparna berjumlah 5 orang.

STIKes Respati sebagai satusatunya sekolah tinggi ilmu kesehatan di Kabupaten Tasikmalaya memiliki tanggung jawab untuk memberikan kontribusi terhadap permasalahan terkait dengan kesehatan di Kabupaten Tasikmalaya melalui kegiatan Tri Dharma Perguruan Tinggi salah satunya dengan kegiatan pengabdian kepada masyarakat.

Salah satu upaya nyata STIKes Respati adalah dengan melaksanakan kegiatan pengabdian kepada masyarakat dengan tema Pemantauan Tumbuh Kembang Balita sebagai upaya peningkatan status gizi untuk dapat membantu terwujudnya kesehatan masyarakat secara umum dan perbaikan status gizi secara khususnya.

\section{B. TUJUAN}

Adapun tujuan kegiatan ini adalah untuk melakukan upaya pemantauan tumbuh kembang balita melalui : 
1. Pemeriksaan status gizi balita sebagai salah satu upaya pemantauan pertumbuhan

2. Lomba merangkak bagi bayi sebagai salah satu upaya pemantauan perkembangan

\section{BENTUK KEGIATAN}

Dalam kegiatan pengabdian kepada masyarakat tersebut dilaksanakan beberapa kegiatan, diantaranya :

1. Pemantauan status gizi balita

2. Lomba merangkak bagi bayi

\section{SASARAN}

Adapun sasaran dalam kegiatan ini adalah :

1. Seluruh balita di Desa Cikunir Kecamatan Singaparna berjumlah 50 balita

2. Peserta lomba merangkak bayi berjumlah 18 orang bayi dengan umur antara 6-9 bulan

\section{E. TEMPAT DAN WAKTU}

Kegiatan dilaksanakan di Aula Graha Bhakti Respati dan dilaksanakan pada Hari Selasa Tanggal 28 November 2017

\section{F. KEPANITIAAN}

Kegiatan dilaksanakan oleh Dosen Program Studi S1 Kesehatan Masyarakat dan Diploma III Kebidanan serta oleh mahasiswa STIKes Respati. Adapun pelaksana kegiatan tersebut adalah :

1. Hariyani Sulistyoningsih, SKM, MKM

2. Annisa Rachmidini, SST, M.Keb
3. Fenty Agustini, SST, M.Kes

4. Hapi Apriasih, SST, M.Keb

5. Lia Yuliastuti, SST, M.Keb

6. Erwina Sumartini, SST, M.Keb

7. Sofha Ramdiani Putri

8. Windi Restuti

9. Marfungah Tunnisa

10. Dina Fitria

\section{G. HASIL KEGIATAN}

Kegiatan pemantauan tumbuh kembang bayi balita diikuti oleh 50 orang bayi balita.

Kegiatan ini terdiri dari :

1. Pemantauan status gizi bayi balita

Dari hasil penimbangan BB dan TB didapatkan bahwa 2 bayi balita dengan ststus gizi kurang.

2. Lomba merangkak

Lomba merangkak ini diikuti oleh bayi berusia $9-12$ bulan yaitu 15 orang.

Kegiatan ini dimenngkan oleh : Juara 1 : Fitra (cikunir) Juara 2 : Farid (cikunir) Juara 3 : M Irsyad (Cikadongdong)

3. Seminar tumbuh kembang bayi balita

Seminar ini dilksanakan bekerjasama dengan RSIA Respati. Materi tentang tumbuh kembang bayi balita oleh dr. Marte, Sp.A. Acara tersebut diikuti oleh 100 ibu bayi balita. 


\section{H. DOKUMENTASI}

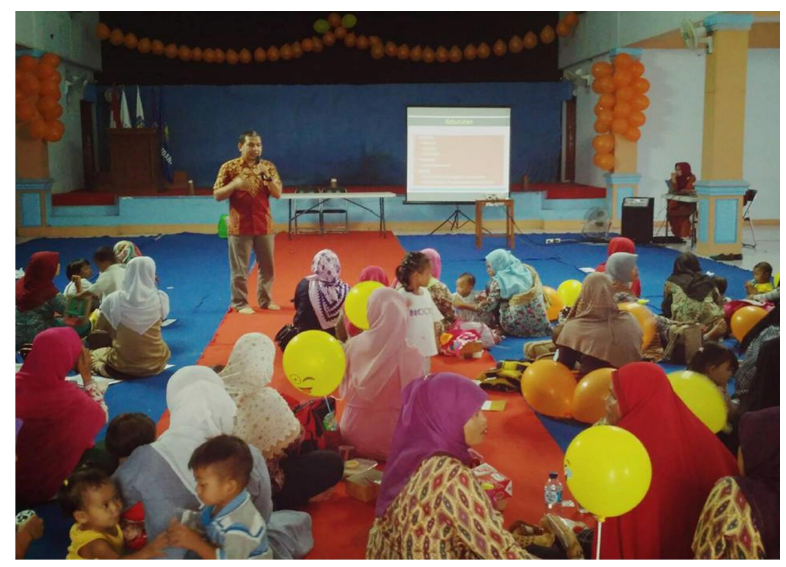

Penyuluhan tumbuh kembang bayi balita
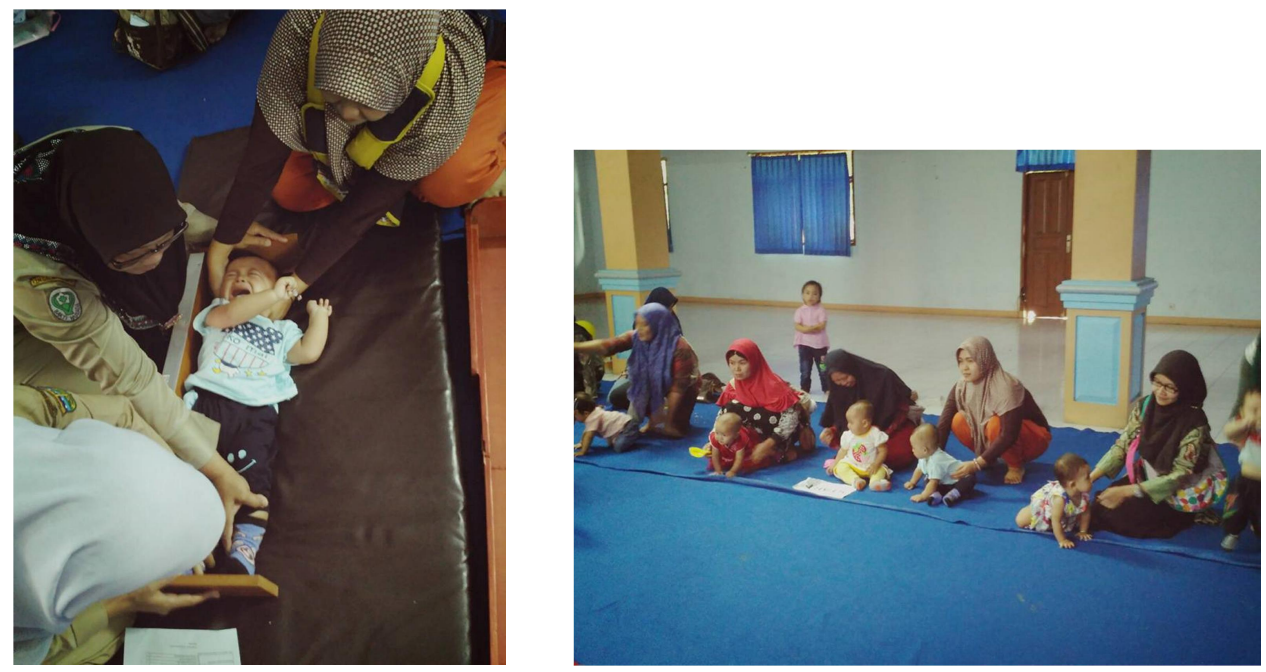

Pemeriksaan status gizi balita dan lomba merangkak 